\title{
Proximate and mineral composition, protein quality of Hibiscus sabdariffa L. (roselle) seeds cultivated in two agro ecological areas in Cameroon
}

\author{
Maffo Tazoho Ghislain ${ }^{1}$, Agbor Esther Etengeneng ${ }^{1}$, Mekoudjou Nouwou Hermine Sonia ${ }^{1}$, \\ Kengne Sikati Christelle Noelle ${ }^{1}$, Gouado Inocent ${ }^{2, *}$.
}

${ }^{1}$ Department of Biochemistry, Faculty of Science, University of Dschang, Dschang, Cameroon

${ }^{2}$ Department of Biochemistry, Faculty of science, University of Douala, Douala, Cameroon

\section{Email address:}

gouadoi@yahoo.fr (Gouado I.)

\section{To cite this article:}

Maffo Tazoho Ghislain, Agbor Esther Etengeneng, Mekoudjou Nouwou Hermine Sonia, Kengne Sikati Christelle Noelle, Gouado Inocent. Proximate and Mineral Composition, Protein Quality of Hibiscus Sabdariffa L. (Roselle) Seeds Cultivated in Two Agro Ecological Areas in Cameroon. International Journal of Nutrition and Food Sciences. Vol. 3, No. 4, 2014, pp. 251-258.

doi: $10.11648 /$ j.ijnfs.20140304.14

\begin{abstract}
The chemical composition and protein quality of raw, boiled, toasted and soak-toasted roselle seeds harvested in the North (area I) and West (area II) regions of Cameroon were investigated in this study. To conduct the growth and nitrogen balance study, sixty albinos wistar rats of 21 to 25 days separated into ten groups of six rats/group were used and fed for fourteen days with $10 \%(\mathrm{w} / \mathrm{w})$ isoproteinous experimental diets. These groups were Protein free diet (D0), egg white-standard reference protein diet (D1) and raw (D2I, D2II), boiled (D3I, D3II), toasted (D4I, D4II) and soak-toasted (D5II, D6II) roselle seed diets. Transaminases, serum creatinine, haematocrit, lipid parameters were also assessed in the rats. Results showed that crude protein, lipid, fiber and ash content of seed samples ranged respectively from 22 to 26,18 to 22,18 to 23 and 4.3 to $6.4 \%$. The contents of $\mathrm{Ca}, \mathrm{Mg}, \mathrm{K}, \mathrm{Na}, \mathrm{P}, \mathrm{Fe}$ and $\mathrm{Zn}$ were ranged from 1054 to 1920,1670 to $2083,26.45$ to $272.7,14$ to $22,10.58$ to $90.78,137.3$ to 169.22 and 10.13 to $70.11 \mathrm{mg} / \mathrm{kg}$ respectively. Food intake was higher $(\mathrm{P}<0.05)$ for groups D1, D3I and D3II than for others groups. The rats fed with reference diet followed by boiled seed diets had the highest $(\mathrm{P}<0.05)$ weight gained, protein efficiency ratio (PER), net protein ratio (NPR), feed efficiency (FE), efficiency of food utilization (EFU) and true digestibility (TD). Aspartate aminotransferase and alanine aminotranferase were highest $(\mathrm{p}<0.05)$ in the rats fed raw roselle seeds. Compared to reference diet, the total cholesterol (TC), triglycerides (TG) and LDL-C of rats fed with diet D5II decreased while the HDL-C did not show any significant changes in these rats ( $\mathrm{p} \square 0.05)$. These findings show that roselle seeds cultivated in Cameroon have important amount of macronutrients and minerals. Proteins of roselle seeds are of good quality especially from the boiled seeds and are not influenced by the agro ecological region. Consumption of roselle seeds might be beneficial for cardio protective effect and no toxicity was observed as far as transaminases are concerned except that for the raw seeds which showed significant hepatotoxicity.
\end{abstract}

Keywords: Roselle Seeds, Chemical Composition, Protein Quality, Transaminases, Lipid Profile, Rats

\section{Introduction}

Malnutrition is an abnormal physiological condition caused by deficiencies, excesses or imbalances in energy, protein and or other nutrients. FAO (2012) reported that 870 million people are estimated to have been undernourished (in terms of dietary energy supply) between 2010 and 2012; 852 million live in developing countries where the prevalence of undernourishment is estimated at $14.9 \%$ of the population. Protein malnutrition is real in most developing countries because of the low animal proteins intake. Meat, fish, milk and eggs provide proteins with satisfactory amino acids pattern as well as bioavailable micronutrients such as iron, zinc, calcium and vitamin A which many malnourished people are deficient. Unfortunately, these proteins are expensive, and most populations from developing countries cannot afford them. Thus, there is a need to look for locally available and cheap sources of feed ingredients particularly those that do not attract competition between humans and livestock. One of such feed ingredient that can be used as 
protein supplement with little or no cost is Hibiscus sabdariffa L. (roselle) seeds. Roselle seeds cultivated in many countries such as Egypt, India, Mali, Malaysia, Nigeria, and Sudan have been found to contain high amount of protein, dietary fiber, lipids, and minerals (Samy, 1980; Rao, 1996; Fatoumata et al., 2011; Hainida et al., 2008; Balogun and Olatidoye, 2012; Abu El Gasim et al., 2008). It is known that many factors can affect the chemical composition of food among which is the geographic area. In Cameroon, Hibiscus sabdariffa is most cultivated in the northern region where $90 \%$ of roselle are produced, $4 \%$ in the East region, 3\% in the center region and 3\% in other regions (Bidima and Melou, 2009). In the northern regions, seeds are used to make "Mbuja" a condiment produced by fermentation of Hibiscus sabdariffa seeds. Mbuja is also known as bikalga (Burkina Faso), dawadawa botso (Niger), datou (Mali), furundu (Soudan) (Parkouda et al., 2008). The antioxidant and probiotic potential of Mbuja have been investigated by Mohamadou et al., (2007). However, little study has been done on the chemical composition and protein quality and digestibility of roselle seeds cultivated in Cameroon. The whole seeds is said to have high protein value, however these grains are not already used as source of protein in the food habits in Cameroon nevertheless these can be utilized as thickener agent in the sauce like soya beans or groundnut usually used. The raw roselle seeds are known to have bitter taste because of the anti-nutritional components like tannins. These anti-nutritional components can be inactivated by processing methods such as moist heat treatment, dry heat treatment and soaking in water (Price et al., 1979; Yacoub and Abdalla, 2007). This study therefore is aimed at determining the proximate and mineral composition, and also investigating the protein quality and digestibility of raw, boiled, toasted and soak-toasted Hibiscus sabdariffa seeds cultivated in Cameroon.

\section{Material and Methods}

\subsection{Plant Material}

Hibiscus sabdariffa L. seeds used for this study were collected in March, 2012 close to the farmers from Adamaoua and West regions of Cameroon. Adamaoua region is in high Guinean savana zone (agro ecological area I) with $1600 \mathrm{~mm}$ rainfall while the west region is in the Western high plateaus zone (agro ecological area II) with 2000 to less than $4000 \mathrm{~mm}$ rainfall. Dried seeds $(2.5 \mathrm{~kg})$ were collected in each area, placed in polyethylene bags and transported directly to the laboratory for processing. The processed seeds were stored in identified tightly corked stainless containers, awaiting chemical composition analysis and formulation of test diets.

\subsection{Preparation of Samples}

Seeds were cleaned by sorting to remove stones and plant debris, and then wash to remove dust.

Raw seeds: Raw cleaned seeds (625 g) from area I and II were milled and incorporated in the diet (D2I and D2II) of rats.

Boiled seeds: Raw cleaned seeds (625 g) from area I and II were washed in the tap water and boiled with 1.5 litters of clean water to dryness for $50 \mathrm{~min}$. Seeds were oven dried at $45^{\circ} \mathrm{C}$, milled and incorporated in the diet (D3I and D3II) of rats.

Toasted seeds: Raw cleaned seeds (625 g) from area I and II were toasted for $7 \mathrm{~min}$, milled and incorporated in diets D4I and D4II of the rats.

Soak-toasted seeds: Raw cleaned seeds (1250 g) from area II were soaked in 3 litters of water for 12 hours in plastic basin, sun-dried for three days then divided into two equal parts. The first part was toasted for $7 \mathrm{~min}$, milled and incorporated in the diet (D5II) while the other part was toasted for $14 \mathrm{~min}$, milled and incorporated in the diet (D6II) of rats.

Egg white: Whole eggs $(\mathrm{n}=30)$ were bought in local market and the white was separated from the yolk and boiled for $30 \mathrm{~min}$, then chopped into small pieces and oven dried at $45^{\circ} \mathrm{C}$. After drying, egg white was milled and the powder obtained incorporated in the diet (D1) of rats.

The boiling and toasting process were done using a stainless steel pot and a kitchen gas cooker (arkays double burner gas stove, model no NK-TH2) while milling was done using an electric blender (moulinex blender).

\subsection{Proximate Composition}

Crude protein, lipid, ash and dry matter were determined according to AOAC (1990) method. Briefly, samples were dried at $105^{\circ} \mathrm{C}$ overnight and dry matter was calculated. Total nitrogen (micro-kjeldahl) was determined and protein was calculated as $\mathrm{N} \times 6.25$. Ash content was determined by incinerating samples at $500^{\circ} \mathrm{C}$ to constant weight. Total lipids were determined by exhaustively extracting a known weight of sample with Ether using a soxhlet apparatus. Crude fiber content was determined using Sharer and Kurschner (1931) method. Each sample was analysed in triplicate.

\subsection{Mineral Composition}

Minerals were determined in samples extracts, prepared by dry-ashing (Pearson, 1981). The amount of zinc and iron were determined by the ammonium molybdate/ammonium vandate method of Chapman and Pratt (1968). Calcium and magnesium were determined by the titration method of Chapman and Pratt (1961). Sodium and potassium were determined according to AOAC (1990) using flame photometer.

\subsection{Formulation of Test Diets}

The experimental diets (table 1) were prepared following ICN (1992) protocol where all diets contained 10\% (w/w) protein except for group D0 (protein-free diet). The protein diets were formulated on the base of their proximate composition. Egg white and roselle seeds were used as a source of protein respectively for reference and test diets. 
Table 1. Formulation of experimental diets

\begin{tabular}{|c|c|c|c|c|c|c|c|c|c|c|}
\hline \multirow{2}{*}{ Ingredient (g/100g) } & \multicolumn{10}{|c|}{ Diet } \\
\hline & D0 & D1 & D2I & D2II & D3I & D3II & D4I & D4II & D5II & D6II \\
\hline Corn starch & 15 & 15 & 15 & 15 & 15 & 15 & 15 & 15 & 15 & 15 \\
\hline Corn oil & 5 & 5 & 5 & 5 & 5 & 5 & 5 & 5 & 5 & 5 \\
\hline Mineral complex & 4 & 4 & 4 & 4 & 4 & 4 & 4 & 4 & 4 & 4 \\
\hline Vitamin complex & 1 & 1 & 1 & 1 & 1 & 1 & 1 & 1 & 1 & 1 \\
\hline Cellulose & 7.9 & 7.9 & 7.9 & 7.9 & 7.9 & 7.9 & 7.9 & 7.9 & 7.9 & 7.9 \\
\hline Protein source & l & 13.9 & 50 & 51 & 40.5 & 43.1 & 42.7 & 43.3 & 48.15 & 47.62 \\
\hline Sucrose & 67.1 & 53.2 & 17.1 & 16.1 & 26.6 & 24 & 24.4 & 23.8 & 18.95 & 19.48 \\
\hline Total & 100 & 100 & 100 & 100 & 100 & 100 & 100 & 100 & 100 & 100 \\
\hline
\end{tabular}

$\mathrm{D} 0=$ protein-free diet, D1 = egg white (standard protein) diet, D2I and D2II =raw roselle seed diets, D3I and D3II = boiled roselle seed diets, D4I and D4II = toasted roselle seed diets, D5II= toasted for $7 \mathrm{~min}$ after soaking for $12 \mathrm{~h}$ roselle seed diets, D6II= toasted for $14 \mathrm{~min}$ after soaking for $12 \mathrm{~h}$ roselle seed diets. $\mathrm{I}=$ agro ecological area I (Adamaoua region). II= agro ecological area II (West region).

\subsection{Protein Quality Evaluation}

Sixty male and female wistar albinos rats aged 21-25 days of 25-35 g range weight, bred in the animal house of the Department of Biochemistry, University of Dschang Cameroon were used. The rats were divided into 10 groups (corresponding to 10 different diets) of 6 rats/group and were housed individually in a plastic cages labelled with stainless steel mesh to ease ventilation. Highly absorbent paper was placed under the cages to catch spilled food and to minimise contamination with faeces and urine. The animal room was well ventilated, cleaned and maintained at room temperature with 12 hours light/dark cycle. Rats were acclimatised for three days followed by ten days experimental period and each animal was supplied ad libitum with diet and water daily. Food intake and body weight were recorded daily. Faeces were collected every day after acclimatization period and the nitrogen content was determined. Based on the nitrogen content of the samples and faeces, the protein efficiency ratio (PER), net protein ratio (NPR), efficiency of food utilization (EFU), feed efficiency (FE) and the true digestibility (TD) of each group were calculated.

\subsection{Biochemical Assay}

At the end of experimental period, each rat was anaesthetized with chloroform in desiccators and immediately dissected using surgical forceps and scissors. Blood was directly obtained from the heart by cardiac punctures at the ventricular region of the heart using $10 \mathrm{ml}$ plastic syringes and needles. After collection, blood was divided into two set: A little volume was transfer in the tube with anticoagulant (EDTA) while the rest was transfer in the tube without anticoagulant. Blood collected in the tubes with anticoagulant was used the same day to investigate haematocrit level. Serum was obtained after centrifugation of the blood collected in the tube without anticoagulant, and stored at $-18^{\circ} \mathrm{C}$ for further analyses. Alanine aminotransferase (ALAT), aspartate aminotranferase (ASAT), creatinine, total cholesterol (TC), triglycerides (TG) and high density lipoprotein cholesterol (HDL-C) were measured using INMESCO (Neustadt/Wied-Germany) standard kits. The concentration of low density lipoprotein cholesterol (LDL-C) was determined using the Friedewald formula (1972). Immediately after blood collection, the liver and kidney of each rat were excised and their relative weight as percentage of body was calculated.

\subsection{Statistical Analyses}

Results were reported as means \pm SD and statistical analyses were done using Graph pad prism version 5.00 software. The following statistical tests were performed: one way ANOVA and Bonferroni. A P value of less than .05 was considered significant.

\section{Results and Discussion}

\subsection{Results}

\subsubsection{Proximate and Mineral Composition of Differently Processed Roselle Seeds}

Table 2 show the proximate composition of roselle seeds. The crude protein values range from 22 for the raw seeds to 26 for boiled seeds. Crude protein of boiled roselle seeds was higher than the rest but there was no significant difference $(p>0.05)$ in protein content with respect to agro ecological area. The total lipid for raw, boiled, toasted and soak-toasted roselle seeds range from 21 to 22,21 to 22,18 to 19 and 20 to $21 \%$ respectively while crude fibers values were $20,19-21,18-20$ and $23 \%$ respectively. There was no significant difference $(\mathrm{p}>0.05)$ in total lipid content. But crude fiber content of soak-toasted seeds was significantly higher $(\mathrm{P}<0.05)$. The ash content of raw seeds was also higher $(\mathrm{P}>0.05)$ than the rest. Table 3 gives an idea of some minerals found in the studied seeds. Roselle seeds cultivated in Cameroon are an important source of magnesium, calcium and potassium. The amounts of calcium, magnesium, potassium and zinc decrease with boiling and soaking. The values of these mineral were range from 1054 to 1920,1670 to $2090,26.45$ to 272.7 and 10.13 to 76.1 $\mathrm{mg} / \mathrm{kg}$ for calcium, magnesium, potassium and zinc respectively. The ash content of roselle seeds cultivated in west region of Cameroon was higher $(\mathrm{P}>0.05)$ than those cultivated in Adamaoua region. 
Table 2. Proximate composition of raw and processed roselle seeds cultivated in Cameroon g/100g DM (dry matter)

\begin{tabular}{llllll}
\hline Sample & $\begin{array}{l}\text { Dry } \\
\text { matter }\end{array}$ & $\begin{array}{l}\text { Crude } \\
\text { protein }\end{array}$ & $\begin{array}{l}\text { Crude } \\
\text { lipid }\end{array}$ & $\begin{array}{l}\text { Crude } \\
\text { fiber }\end{array}$ & Ash \\
\hline D1 & $90 \pm 0.01^{\mathrm{g}}$ & $80 \pm 1.1^{\mathrm{a}}$ & $1.1 \pm 0.02^{\mathrm{d}}$ & $1.8 \pm 0,03^{\mathrm{d}}$ & $6.9 \pm 1.0^{\mathrm{a}}$ \\
D2I & $90 \pm 0.04^{\mathrm{f}}$ & $22 \pm 1.0^{\mathrm{c}}$ & $22 \pm 0.99^{\mathrm{a}}$ & $20 \pm 0.96^{\mathrm{b}}$ & $5.7 \pm 0.03^{\mathrm{a}}$ \\
D2II & $89 \pm 0.01^{\mathrm{h}}$ & $22 \pm 1.0^{\mathrm{c}}$ & $21 \pm 1.5^{\mathrm{abc}}$ & $20 \pm 1.1^{\mathrm{bc}}$ & $6.4 \pm 0.04^{\mathrm{a}}$ \\
D3I & $95 \pm 0.02^{\mathrm{d}}$ & $26 \pm 1.0^{\mathrm{b}}$ & $22 \pm 1.0^{\mathrm{a}}$ & $19 \pm 1.0^{\mathrm{bc}}$ & $4.3 \pm 1.0^{\mathrm{b}}$ \\
D3II & $95 \pm 0.04^{\mathrm{c}}$ & $25 \pm 1.1^{\mathrm{bc}}$ & $21 \pm 1.0^{\mathrm{abc}}$ & $21 \pm 0.01^{\mathrm{ba}}$ & $5.2 \pm 1.0^{\mathrm{ab}}$ \\
D4I & $99 \pm 0.02^{\mathrm{b}}$ & $24 \pm 1.1^{\mathrm{bc}}$ & $19 \pm 1.0^{\mathrm{bc}}$ & $20 \pm 1.0^{\mathrm{bc}}$ & $5.9 \pm 0.02^{\mathrm{a}}$ \\
D4II & $99 \pm 0.07^{\mathrm{a}}$ & $23 \pm 0.9^{\mathrm{bc}}$ & $18 \pm 0.8^{\mathrm{c}}$ & $18 \pm 1.1^{\mathrm{c}}$ & $4.8 \pm 0.02^{\mathrm{b}}$ \\
D5II & $88 \pm 0.03^{\mathrm{i}}$ & $24 \pm 1.1^{\mathrm{bc}}$ & $21 \pm 0.16^{\mathrm{abc}}$ & $23 \pm 0.02^{\mathrm{a}}$ & $5.5 \pm 1.2^{\mathrm{a}}$ \\
D6II & $90 \pm 0.07^{\mathrm{e}}$ & $23 \pm 1.1^{\mathrm{bc}}$ & $20 \pm 1.0^{\mathrm{abc}}$ & $23 \pm 0.02^{\mathrm{a}}$ & $5.6 \pm 1.0^{\mathrm{a}}$ \\
\hline
\end{tabular}

Values are means $\pm \mathrm{SD}$. Means in the same column followed by the same letters are not significantly different at $5 \%$ probability. $\mathrm{SD}=$ standard deviation, D1= egg white (standard protein), D2I and D2II =raw roselle seeds, D3I and D3II = boiled roselle seeds, D4I and D4II = toasted roselle seeds, D5II = toasted for $7 \mathrm{~min}$ after soaking for $12 \mathrm{~h}, \mathrm{D} 6 \mathrm{II}=$ toasted for 14 min after soaking for $12 \mathrm{~h}$. DM= dry matter $\mathrm{I}=$ agro ecological area $\mathrm{I}$ (Adamaoua region). II= agro ecological area II (West region).

\subsubsection{Protein Quality and Digestibility of Differently Processed Roselle Seeds}

The performance of rats fed with differently processed roselle seeds are shown in table 4 . The food intake of rats fed with diets D1, D3I and D3II was significantly higher $(p<0.05)$ than the rest. The weight gained of rat fed with boiled seeds was significantly higher $(p<0.05)$ than the other processed seeds. The food intake of rats fed with diet D0 was lowest $(\mathrm{p}<0.05)$ and the rats of this group were losing their weight. The weight gained of rats fed with standard protein
(D1) was significantly higher $(\mathrm{p}<0.05)$ than the raw, boiled, toasted and soak-toasted seed diets. The protein consumed by each group during the test period was paralleled with the total food intake. The protein consumed by rats fed with D1 (reference diet) was the highest $(p<0.05)$ followed respectively by boiled (D3I and D3II), soak-toasted (D5II and D6II), toasted (D4I and D4II) and raw (D2I and D2II) seed diets. The average feed conversion ratios for the treatment group were 15, 7.2-9.6, 3.8-4.7 and 3.1-3.4 g/g for raw, toasted, soak-toasted and boiled seed diets respectively. The feed efficiency of reference diet was the lowest. In addition, the total faeces collected were higher in boiled seed diets than in other processed seed diets. This is reflected in total food consumption of the rats.

Table 3. Mineral composition $(\mathrm{mg} / \mathrm{kg})$ of raw and processed roselle seeds cultivated in Cameroon

\begin{tabular}{llllllll}
\hline Sample & $\mathbf{C a}$ & $\mathbf{M g}$ & $\mathbf{K}$ & $\mathbf{N a}$ & $\mathbf{P}$ & $\mathbf{F e}$ & $\mathbf{Z n}$ \\
\hline D2I & 1750 & 1985 & 30.52 & 22 & 10.58 & 137.3 & 63.5 \\
D2II & 1920 & 2083 & 272.7 & 14 & 35.82 & 147.5 & 76.1 \\
D3I & 1054 & 1670 & 26.45 & 21 & 20.73 & 145.02 & 21.3 \\
D3II & 1160 & 1989 & 232.6 & 15 & 80.60 & 169.22 & 10.13 \\
D4I & 1710 & 1895.5 & 31.8 & 24 & 90.78 & 140.01 & 46.91 \\
D4II & 1860 & 2090 & 272.7 & 18 & 18.92 & 152.5 & 52.6 \\
D5II & 1260 & 1898 & 205.45 & 21 & 40.52 & 148.7 & 69.8 \\
D6II & 1262 & 1850 & 206.9 & 20 & 42.03 & 149.03 & 70.11 \\
\hline
\end{tabular}

D2I and D2II =raw roselle seeds, D3I and D3II = boiled roselle seeds, D4I and D4II = toasted roselle seeds, D5II= toasted for 7 min after soaking for $12 \mathrm{~h}$, D6II= toasted for $14 \mathrm{~min}$ after soaking for $12 \mathrm{~h}$. I= agro ecological area I (Adamaoua region). II= agro ecological area II (West region).

Table 4. Performance of rats fed with experimental diets for 10 days

\begin{tabular}{llllll}
\hline Diet & Food intake(g) & Weight gained $(\mathbf{g})$ & Protein consumed $(\mathrm{g})$ & Feed efficiency $(\mathrm{g} / \mathrm{g})$ & Feces weight $(\mathrm{g})$ \\
\hline D0 & $16 \pm 3.6^{\mathrm{d}}$ & $-1.6 \pm 0.8^{\mathrm{e}}$ & RNA & RNA & $0.7 \pm 0.32^{\mathrm{c}}$ \\
D1 & $87 \pm 7.8^{\mathrm{a}}$ & $42 \pm 4.3^{\mathrm{a}}$ & $8.7 \pm 0.79^{\mathrm{a}}$ & $2.1 \pm 0.1^{\mathrm{c}}$ & $3.6 \pm 0.33^{\mathrm{b}}$ \\
D2I & $28 \pm 2.5^{\mathrm{b}}$ & $2.0 \pm 0.51^{\mathrm{c}}$ & $2.8 \pm 0.25^{\mathrm{b}}$ & $15 \pm 3.3^{\mathrm{a}}$ & $14 \pm 1.9^{\mathrm{a}}$ \\
D2II & $28 \pm 2.6^{\mathrm{b}}$ & $1.9 \pm 0.37^{\mathrm{c}}$ & $2.8 \pm 0.26^{\mathrm{b}}$ & $15 \pm 2.9^{\mathrm{a}}$ & $9.9 \pm 1.2^{\mathrm{a}}$ \\
D3I & $73 \pm 18^{\mathrm{a}}$ & $21 \pm 6.3^{\mathrm{b}}$ & $7.3 \pm 1.8^{\mathrm{a}}$ & $3.4 \pm 0.23^{\mathrm{c}}$ & $13 \pm 2.8^{\mathrm{a}}$ \\
D3II & $73 \pm 8.8^{\mathrm{a}}$ & $24 \pm 3.0^{\mathrm{b}}$ & $7.3 \pm 0.88^{\mathrm{a}}$ & $3.1 \pm 0.14^{\mathrm{c}}$ & $14 \pm 2.5^{\mathrm{a}}$ \\
D4I & $31 \pm 7.4^{\mathrm{b}}$ & $3.3 \pm 0.92^{\mathrm{c}}$ & $3.0 \pm 0.79^{\mathrm{b}}$ & $9.6 \pm 0.69^{\mathrm{b}}$ & $4.6 \pm 1.1^{\mathrm{b}}$ \\
D4II & $31 \pm 2.2^{\mathrm{b}}$ & $4.3 \pm 0.59^{\mathrm{c}}$ & $3.0 \pm 0.79^{\mathrm{b}}$ & $7.2 \pm 0.95^{\mathrm{bd}}$ & $4.5 \pm 0.84^{\mathrm{b}}$ \\
D5II & $51 \pm 1.4^{\mathrm{c}}$ & $14 \pm 2.4^{\mathrm{d}}$ & $5.0 \pm 0.24^{\mathrm{c}}$ & $3.8 \pm 0.52^{\mathrm{c}}$ & $12 \pm 1.6^{\mathrm{a}}$ \\
D6II & $51 \pm 1.4^{\mathrm{c}}$ & $11 \pm 1.5^{\mathrm{d}}$ & $5.0 \pm 0.27^{\mathrm{c}}$ & $4.7 \pm 0.46^{\mathrm{cd}}$ & $9.8 \pm 1.1^{\mathrm{a}}$ \\
\hline
\end{tabular}

Values are means $\pm \mathrm{SD}(\mathrm{n}=6)$. Means in the same column followed by the same letters are not significantly different at $5 \%$ probability. $\mathrm{SD}=$ standard deviation, D0= protein-free diet, D1 = egg white (standard protein) diet, D2I and D2II =raw roselle seed diets, D3I and D3II = boiled roselle seed diets, D4I and D4II = toasted roselle seed diets, D5II= toasted for $7 \mathrm{~min}$ after soaking for $12 \mathrm{~h}$ roselle seed diets, D6II= toasted for 14 min after soaking for $12 \mathrm{~h}$ roselle seed diets. I= agro ecological area I (Adamaoua region). II= agro ecological area II (West region). $\mathrm{RNA}=$ results are not available. 
Table 5. Efficiency of food utilization (EFU), Protein efficiency ratio (PER), Net protein ration (NPR) and True digestibility (TD) of rats fed with experimental diets.

\begin{tabular}{lllll}
\hline Diet & EFU (\%) & PER & NPR & TD (\%) \\
\hline D1 & $48 \pm 2.6^{\mathrm{a}}$ & $4.9 \pm 0.26^{\mathrm{a}}$ & $4.5 \pm 0.27^{\mathrm{a}}$ & $95 \pm 1.3^{\mathrm{a}}$ \\
D2I & $7.1 \pm 1.3^{\mathrm{d}}$ & $0.79 \pm 0.12^{\mathrm{d}}$ & $0.22 \pm 0.07^{\mathrm{c}}$ & $56 \pm 9.3^{\text {ef }}$ \\
D2II & $6.9 \pm 1.2^{\mathrm{d}}$ & $0.75 \pm 0.03^{\mathrm{d}}$ & $0.19 \pm 0.05^{\mathrm{c}}$ & $3 \pm 7.6^{\mathrm{f}}$ \\
D3I & $29 \pm 0.26^{\mathrm{be}}$ & $2.9 \pm 0.26^{\mathrm{be}}$ & $2.6 \pm 0.71^{\mathrm{b}}$ & $79 \pm 5.1^{\mathrm{b}}$ \\
D3II & $32 \pm 1.1^{\mathrm{b}}$ & $3.2 \pm 0.18^{\mathrm{b}}$ & $2.9 \pm 0.8^{\mathrm{b}}$ & $80 \pm 4.4^{\mathrm{b}}$ \\
D4I & $10 \pm 0.71^{\text {cd }}$ & $1.2 \pm 0.25^{\text {cd }}$ & $0.32 \pm 0.07^{\mathrm{c}}$ & $63 \pm 2.4^{\text {def }}$ \\
D4II & $13 \pm 1.3^{\mathrm{c}}$ & $1.3 \pm 0.13^{\mathrm{c}}$ & $0.41 \pm 0.14^{\mathrm{c}}$ & $65 \pm 2.7^{\text {cde }}$ \\
D5II & $27 \pm 3.6^{\mathrm{e}}$ & $2.6 \pm 0.37^{\mathrm{e}}$ & $2.5 \pm 0.27^{\mathrm{b}}$ & $74 \pm 3.4^{\mathrm{bc}}$ \\
D6II & $22 \pm 2.4^{\mathrm{f}}$ & $2.0 \pm 0.41^{\mathrm{f}}$ & $1.8 \pm 0.3^{\mathrm{d}}$ & $72 \pm 5.2^{\mathrm{bcd}}$ \\
\hline
\end{tabular}

Values are means $\pm \mathrm{SD}(\mathrm{n}=6)$. Means in the same column followed by the same letters are not significantly different at $5 \%$ probability. $\mathrm{SD}=$ standard deviation, D0= protein-free diet, D1 = egg white (standard protein) diet, D2I and D2II =raw roselle seed diets, D3I and D3II = boiled roselle seed diets, D4I and D4II = toasted roselle seed diets, D5II= toasted for $7 \mathrm{~min}$ after soaking for $12 \mathrm{~h}$ roselle seed diets, D6II= toasted for 14 min after soaking for $12 \mathrm{~h}$ roselle seed diets. I= agro ecological area I (Adamaoua region). II= agro ecological area II (West region).

The values of PER, EFU, NPR and TD are presented in table 5. The EFU (efficiency of food utilization) of rats fed with standard diet (D1) was significantly higher $(\mathrm{p}<0.05)$ than the rest. This highest value observed for diet D1 was followed by D3II, D3I, D5II, D6II, D4II, D4I, D2I and D2II with EFU values of 32, 29, 27, 22, 13, 10, 7.1 and $6.9 \%$ respectively. The EFU of rats fed with diet D3II (from West region) was higher than those of diet D3I (from Adamaoua region) and the EFU of rats fed with diet D5II (seeds toasted for 7 min after soaking for $12 \mathrm{~h}$ ) was higher than D6II (seeds toasted for $14 \mathrm{~min}$ after soaking for $12 \mathrm{~h}$ ). The protein efficiency ratio (PER) for each group during the test period paralleled the efficiency of food utilization (EFU). The lowest value of PER was found for raw seed diets followed by toasted seed diets with values range from 0.75 to 0.79 and 1.2 to 1.3 respectively. The NPR and TD values of diet D1 was the highest $(p<0.05)$ followed respectively by boiled (D3II, D3I), soak-toasted (D5II, D6II), toasted (D4II, D4I) and raw (D2I, D2II) seed diets.

\subsubsection{Effect of Roselle Seed Diets on Serum Enzyme and Haematocrit of Rats}

Table 6 shows the results of haematocrit, aspartate aminotransferase (ASAT), alanine aminotransferase (ALAT) and creatinine. The results of haematocrit and creatinine have shown no significant difference $(p>0.05)$ between the different diets. However, ALAT level of rats was significantly higher $(\mathrm{p}<0.05)$ when feeding with diets D2I and D2II (raw seeds) compared to diet D1 (reference diet). Likewise ASAT was significantly higher $(\mathrm{p}<0.05)$ for rats fed with raw (D2I and D2II) and also toasted (D4I and D4II) seed diets than for those fed with diet D1. The relative weight of liver of rats feeding with different diets was the same except for rats fed with raw seed diets where the relative weight of liver was significantly higher $(p<0.05)$ compared to rats fed with diet D1. Furthermore, we have also noticed a significant increase $(\mathrm{p}<0.05)$ of the relative weight of kidney of rats fed with raw (D2I and D2II) and toasted (D4I and D4II) seed diets compared with diet D1.

Table 6. Effect of experimental diets on few parameters (haematocrit, ASAT, ALAT) and relative weight of liver and kidney of rats.

\begin{tabular}{lllllll}
\hline Diet & $\begin{array}{l}\text { Haematocrit } \\
(\%)\end{array}$ & $\begin{array}{l}\text { ALAT } \\
(\mathbf{U I} / \mathbf{L})\end{array}$ & $\begin{array}{l}\text { ASAT } \\
(\mathbf{U I} / \mathbf{L})\end{array}$ & $\begin{array}{l}\text { Creatinine } \\
(\mathbf{m g} / \mathbf{d L})\end{array}$ & $\begin{array}{l}\text { Relative weight } \\
\text { liver }(\%)\end{array}$ & $\begin{array}{l}\text { of } \\
\text { Relative } \\
\text { kidney }(\%)\end{array}$ \\
\hline D1 & $31 \pm 4.1^{\mathrm{a}}$ & $18 \pm 8.0^{\mathrm{b}}$ & $73 \pm 5.0^{\mathrm{e}}$ & $1.4 \pm 0.31^{\mathrm{a}}$ & $4.8 \pm 0.34^{\mathrm{b}}$ & $0.9 \pm 0.07^{\mathrm{b}}$ \\
D2I & $32 \pm 2.9^{\mathrm{a}}$ & $31 \pm 3.6^{\mathrm{a}}$ & $123 \pm 13^{\mathrm{a}}$ & $1.6 \pm 0.08^{\mathrm{a}}$ & $5.5 \pm 0.12^{\mathrm{a}}$ & $1.2 \pm 0.01^{\mathrm{a}}$ \\
D2II & $32 \pm 2.9^{\mathrm{a}}$ & $32 \pm 3.2^{\mathrm{a}}$ & $116 \pm 9.9^{\mathrm{ba}}$ & $1.4 \pm 0.31^{\mathrm{a}}$ & $5.5 \pm 0.14^{\mathrm{a}}$ & $1.2 \pm 0.01^{\mathrm{a}}$ \\
D3I & $33 \pm 2.6^{\mathrm{a}}$ & $25 \pm 1.9^{\mathrm{ab}}$ & $94 \pm 12^{\mathrm{ce}}$ & $1.2 \pm 0.36^{\mathrm{a}}$ & $4.4 \pm 0.38^{\mathrm{b}}$ & $1.0 \pm 0.07^{\mathrm{b}}$ \\
D3II & $34 \pm 2.0^{\mathrm{a}}$ & $27 \pm 1.7^{\mathrm{ab}}$ & $94 \pm 15^{\mathrm{de}}$ & $1.4 \pm 0.31^{\mathrm{a}}$ & $4.4 \pm 0.09^{\mathrm{b}}$ & $1.0 \pm 0.07^{\mathrm{b}}$ \\
D4I & $28 \pm 4.1^{\mathrm{a}}$ & $21 \pm 5.2^{\mathrm{b}}$ & $114 \pm 9.8^{\mathrm{abd}}$ & $1.2 \pm 0.36^{\mathrm{a}}$ & $4.3 \pm 0.11^{\mathrm{b}}$ & $1.2 \pm 0.05^{\mathrm{a}}$ \\
D4II & $30 \pm 4.1^{\mathrm{a}}$ & $21 \pm 3.9^{\mathrm{b}}$ & $113 \pm 7.6^{\text {abc }}$ & $1.2 \pm 0.37^{\mathrm{a}}$ & $4.4 \pm 0.37^{\mathrm{b}}$ & $1.2 \pm 0.08^{\mathrm{a}}$ \\
D5II & $30 \pm 1.5^{\mathrm{a}}$ & $24 \pm 3.8^{\mathrm{ab}}$ & $89 \pm 11^{\mathrm{e}}$ & $1.4 \pm 0.31^{\mathrm{a}}$ & $4.8 \pm 0.16^{\mathrm{b}}$ & $1.0 \pm 0.01^{\mathrm{b}}$ \\
D6II & $33 \pm 5.5^{\mathrm{a}}$ & $25 \pm 4.5^{\mathrm{ab}}$ & $93 \pm 7.4^{\mathrm{ce}}$ & $1.3 \pm 0.29^{\mathrm{a}}$ & $4.2 \pm 0.3^{\mathrm{b}}$ & $1.0 \pm 0.01^{\mathrm{b}}$ \\
\hline
\end{tabular}

Values are means $\pm \mathrm{SD}(\mathrm{n}=6)$. Means in the same column followed by the same letters are not significantly different at $5 \%$ probability. $\mathrm{SD}=$ standard deviation, D0= protein-free diet, D1 = egg white (standard protein) diet, D2I and D2II =raw roselle seed diets, D3I and D3II = boiled roselle seed diets, D4I and D4II = toasted roselle seed diets, D5II= toasted for 7 min after soaking for $12 \mathrm{~h}$ roselle seed diets, D6II= toasted for 14 min after soaking for $12 \mathrm{~h}$ roselle seed diets. I= agro ecological area I (Adamaoua region). II= agro ecological area II (West region). 


\subsubsection{Effect of Roselle Seed Diets on Lipid Profile of Rats}

The lipid profile that is total cholesterol (TC), triglycerides, HDL-C was investigated, and LDL-C as well as the correlation between HDL-C, TC and LDL-C is shown in figure 1. Compared to the reference diet (D1), the total cholesterol (TC), triglycerides (TG) and LDL-C of rats fed with diet D5II (soak-toasted for $7 \mathrm{~min}$ ) decreased while the HDL-C were not significant different at $p<0.05$. However, the average serum TC level increased $(p>0.05)$ while the TG level decreased $(p>0.05)$ with other seed base diets compared with the reference diet. Besides, the correlation between HDL-C with TC and LDL-C was negative and not significant $(\mathrm{p}>0.05)$ while a significant $(\mathrm{p}<0.05)$ positive correlation was observed between LDL-C and TC.

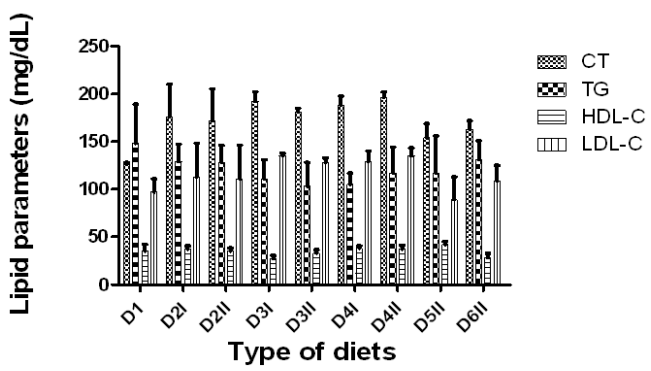

Figure 1. Effect of experimental diets on lipid profile [total cholesterol (TC) triglycerides (TG), high density lipoprotein cholesterol (HDL-C) and low density lipoprotein cholesterol (LDL-C)] of rats.

Values are means $\pm \mathrm{SD}(\mathrm{n}=6) . \mathrm{SD}=$ standard deviation, $\mathrm{D} 1=$ egg white (standard protein) diet, D2I and D2II =raw roselle seed diets, D3I and D3II = boiled roselle seed diets, $\mathrm{D} 4 \mathrm{I}$ and $\mathrm{D} 4 \mathrm{II}=$ toasted roselle seed diets, $\mathrm{D} 5 \mathrm{II}=$ toasted for $7 \mathrm{~min}$ after soaking for $12 \mathrm{~h}$ roselle seed diets, D6II= toasted for $14 \mathrm{~min}$ after soaking for $12 \mathrm{~h}$ roselle seed diets. I= agro ecological area I (Adamaoua region). $\mathrm{II}=$ agro ecological area II (West region).

\subsection{Discussion}

\subsubsection{Proximate and Mineral Composition of Differently Processed Roselle Seeds}

The determination of the macro and micronutrient content of a food give an idea on its nutritive value. The crude protein content was $22 \%$ for raw seeds and was ranged from 23 to $24 \%$ for toasted and soak-toasted seeds and from 25 to $26 \%$ for boiled seeds. These results were similar to the values 22.20, 24.41 and $23.90 \%$ obtained by Bozinviya et al. (2010) for raw, soaking and toasted seeds respectively. However, these results were low compared to the $34 \%$ obtained by Samy (1980) in the raw roselle seeds cultivated in Egypt. Compared to raw seeds, the slightly increase of crude protein content in boiled, toasted and soak-toasted roselle seeds are in conformity with those of Akinmutimi (2001) who showed that the crude protein level of legume seeds subjected to heating increase slightly. The crude lipid, fibre and ash content of raw seeds were respectively ranged from 21 to $22 \%, 20 \%$ and 5.7 to $6.4 \%$. These results are similar to those of El-Adawy et al. (1994) who obtained the crude lipid, fiber and ash content ranging from 16 to $23.3 \%$, 1.2 to $16.8 \%$ and 4.8 to $7.0 \%$ respectively in the raw seeds. The values of dry matter were low compared to the values 92 and $91 \%$ respectively for raw and toasted seeds but were higher than the value $94 \%$ for toasted seeds as obtained by Bozinviya et al. (2010). The calcium, potassium and phosphorus content of raw seeds were higher respectively than the values $2.79-2.95,1.65-1.88$ and $1.26-1.49 \mathrm{mg} / \mathrm{kg}$ obtained by Parkouda et al. (2008). The results of decreasing of minerals content in boiled and soaked seeds are similar to those obtained by Gasim et al. (2008). Globally, the chemical composition of seeds from west region (Western high plateaus zone) was slightly higher than those from Adamaoua region (Guinean savana zone). Raw roselle seeds from Adamaoua region recorded higher mean dry matter content than that of West region. These results are similar to those of William et al. (2013) obtained with Moringa oleifera plant cultivated in two agro ecological area in Ghana where Moringa leaves from Guinea savanna zone recorded the higher dry matter content than that of the semi-deciduous forest zone. The crude protein content was the same in the two agro ecological zones. These results are not in agreement with the findings of Modi (2007) who reported that cool environmental conditions are associated with high total protein in leafy vegetables while hot temperatures had a significant decrease in leaf protein content. Except the $\mathrm{Na}$ content, the $\mathrm{Ca}, \mathrm{Mg}, \mathrm{K}, \mathrm{P}, \mathrm{Fe}$ and $\mathrm{Zn}$ contents of raw seeds from West region were higher than those of the Adamaoua region. This may be due to the long period of dry season (higher temperatures) in the Adamaoua region which makes soils dry for longer period of time inhibiting the absorption of soil nutrients for plant development. Kessel (2005) reported that calcium and potassium levels in plants decreased with decreasing soil moisture. Besides the processing increase the availability of the chemical composition of seeds $(\mathrm{p}<0.05)$. These results are similar to those obtained by Mbah et al. (2012) who state that boiling and roasting increase the availability of protein, fiber, vitamin A, iron and zinc in Moringa oleifera seeds.

\subsubsection{Protein Quality and Digestibility of Differently Processed Roselle Seeds}

Based on the findings, boiling followed by soak-toasted has been shown to improve the protein quality and digestibility of roselle seeds. The food intake, weight gained, EFU, PER, NPR and TD values were higher for boiled (D3I and D3II) and soak-toasted (D5II and D5II) than for raw seed diets. These results were in agreement with those of Halimatul et al. (2007) who investigated the protein quality of two sets of roselle seeds processed differently (dried and boiled) in rats feeding for four weeks and reported that food intake, weight gained, PER and NPR values of rats were significantly higher when feeding with boiled seed than with dried seed diets. Duwa et al. (2012) who evaluated the effect of different processing methods of sorrel seeds (roasting, boiling and soaking) on the productive performance of broilers also found similar results showing that protein quality of boiled roselle seeds was higher than raw and soaked roselle seeds. These results could be explained by the 
inhibition or elimination of anti-nutritional factors during treatment. The roselle seeds in their raw state are known to have bitter taste, which is attributed to anti-nutritional activities. Tannin is one of the anti-nutritionals which is known to have detrimental effect on the health and growth of animals (Jansman, 1993). Although, anti-nutritional factors are found to affect the protein quality of food, many of them can be inactivated by humid or moist heat treatment and dry heat treatment and soaking in water (Price et al., 1979). Duwa et al. (2012) in their research have shown that tannins content in toasted, boiled and soaked seeds were reduced for about 20, 68 and $36 \%$ respectively. According to these results, the boiling is better to toasting and soaking in reduction of tannins content. In the present study, we combined toasting and soaking and the results of protein quality was better with soak-toasted seeds than toasted seeds. The both combined treatments would allow the best inactivation of tannins content compared to raw and toasted grains. The average feed efficiency (FE) of the treatment groups were 15, 7.2-9.6, 3.8-4.7 and 3.1-3.4 g/g respectively for raw, toasted, soak-toasted and boiled seed diets. The feed efficiency (FE) which is the feed consumed per unit weight gain differ among all the treatment groups. Since FE is a measure of the efficiency of rats to convert feed consumed into flesh, the lower the value, the better the FE. Thus, the results of this study indicate that the FE of boiled roselle seeds is the best followed by that of soak-toasted roselle seeds.

\subsubsection{Effect of Roselle Seed Diets on Some Serum Enzyme and Haematocrit of Rats}

Serum enzymes (ALAT, ASAT and creatinine) are often used in clinical diagnosis to assess the integrity of certain body organs. The decreasing of some liver functions enzymes suggests some level of hepatoprotective effect of roselle seeds. In this study ALAT of rats fed raw seed diets was significantly higher as well as ASAT of rats fed raw and toasted seed diets compared to those of reference diet. In addition, the relative weight of liver and kidney of rats fed raw seed diets was significantly higher. This increasing of ASAT and ALAT levels in rat fed raw seeds may be a sign of the deterioration of hepatocytes membrane. The increase of ASAT and ALAT levels is a sign of the deterioration of hepatocytes membrane integrity. This therefore indicates the raw seeds based diet may be toxic for animal consumption. The estimation of haematocrit level in rats fed with the test diets gives an idea of the physiological condition of blood and reticulo endothelial system. There was no significant variation in haematocrit level of rats. Therefore the consumption of roselle seed diets could have any negative effect on blood and reticulo endothelial system.

\subsubsection{Effect of Roselle Seed Diets on Lipid Profile of Rats}

Hyperlipidemia is a risk factor of coronarian pathologies. The elevation of TC and LDL-C is associated to an increase of coronarian risk. In this study, the total cholesterol, triglycerides and LDL-C of rats fed with diet D5II (toasted for $7 \mathrm{~min}$ ) decreased while the HDL-C did not have a significant increase $(p>0.05)$. Furthermore, even if the TC and LDL-C increased in other seeds based diets, the values remains in the normal range $(<150 \mathrm{mg} / \mathrm{dL}$ for $\mathrm{TC}$ and $<130$ $\mathrm{mg} / \mathrm{dL}$ for LDL-C). Besides, the correlation between HDL-C with TC and LDL-C was negative and not significant $(\mathrm{p}>0.05)$. A positive correlation was observed between LDL-C and TC. These results were similar to those obtained by Hainida et al. (2008) who observed significant negative correlations between HDL-C with TC and LDL-C and a positive correlation between LDL-C and TC after inclusion of $50 \mathrm{~g} / \mathrm{kg}$ and $150 \mathrm{~g} / \mathrm{kg}$ of dried roselle seeds in the diet of rats. Since HDL-C is negatively correlated to coronary heart diseases, consumption of roselle seeds might have a cardio protective effect. This could be due to the dietary fiber present in roselle seeds. Marlett (2001) shown that fiber-rich foods such as grains and legumes have important effects on serum cholesterol. Dietary fibers may lower serum cholesterol by modifying the bile acid absorption and metabolism, interfering with lipids absorption and metabolism, producing short chain fatty acids from fiber fermentation in colon and altering the concentrations of insulin and hormones (Anderson et al., 1990).

\section{Conclusion}

The observation made in the present study show that Hibiscus sabdariffa L. seeds cultivated in the Adamaoua and West regions of Cameroon is rich in crude protein, fiber, lipid and some minerals. This study has shown that roselle seeds in their different processed state have good protein quality especially for boiled seeds. The protein quality of roselle seeds cultivated in the West region was slightly higher than those cultivated in the Adamaoua region. The protein quality of roselle seeds toasted for $7 \mathrm{~min}$ was slightly higher than those toasted for 14 min after soaking. Thus, roselle seeds can be exploited as an alternate protein source to alleviate protein-energy-malnutrition. In addition, consumption of roselle seeds might have a cardio protective effect. However, raw roselle seeds are toxic with respect to transaminases and creatinine and the relative weight of liver and kidney of rats.

\section{References}

[1] Abu El Gasim A. Y., Mohammed A. M. and A. A. B. Asma, 2008. Effect of soaking, sprouting and cooking on chemical composition, bioavailability of minerals and in vitro protein digestibility of Roselle (Hibiscus sabdariffa L.) seeds. Pakistan J. Nutr., 7 (1): 50-56.

[2] Akinmutimi A. H., 2001. Soaked and toasted Lima beans (Phaseolus lunatus) in broiler chickens diets: Effects on haematological parameters and blood chemistry. In: Meeting the challenges of animal production in new millennium (C.O. Ubosi, A. Kibon, I.D. Kwari, J.U. Igwebuike, I.D. Mohammed, N.K. Alade, F.I. Abbator and S.B. Adamu) (Eds) $6^{\text {th }}$ Annual Conference of the Animal Science Association of Nigeria, University of Maiduguri, Maiduguri convocation square, pp: 48-49. 
[3] Anderson J. W., D. A. Deakins, T. L. Floore, Smith B. M. and S. S. Whitis, 1990. Dietary fiber and coronary heart disease. Food Sci. Nutr., 29: 95-147.

[4] AOAC, 1990. Association of Official Analytical Chemists. Official Methods of Analysis, $15^{\text {th }}$ Edn., Washington DC.

[5] Balogun I. O. and O. P. Olatidoye, 2012. Chemical composition and nutritional evaluation of velvet bean seeds (Mucuna utilis) for domestic consumption and industrial utilization in Nigeria. Pakistan J. Nutr., 11 (2): 116-122.

[6] Bidima I. M. and M. Melou, 2009. L'oseille de Guinée ou foléré : une culture bien rentable ! où et comment le produire, comment tirer profit de ses multiples usages. La voix du paysan. Mensuel d'information, de formation et de débat sur le monde rural. Rubrique feuille économique, 26 Mai.

[7] Bozinviya J. A., M. S. Yahaya, and J. Nyameh, 2010. Effect of sorrel seed Hibiscus sabdariffa supplementation on the performance of yankasa rams fed Brachiaria decumbens as basal diet. J. Agric. Veterinary Sci., 2: 8-16.

[8] Chapman H. D. and F. P. Pratt, 1961. Calcium and magnesium by titration methods: Methods of analysis for soils, plants and water. California Univ. Public. Div. Agric. Sci., pp: 20

[9] Chapman H. D. and F. P. Pratt, 1968. Ammonium molybdate-Ammonium vandate method for determination of phosphorus: Methods of analysis for soils, plants and water. California Univ. Public. Div. Agric. Sci., pp: 169-170.

[10] Duwa H., E. O. Oyawoye and A. A. Njidda, 2012. Effect of processing methods on the Utilization of sorrel seed meal by broilers. Pakistan J. Nutr., 11(1): 38-46.

[11] El-Adawy T. A. and A. H. Khalil, 1994. Characteristic of roselle seeds as a new source of protein and lipid. J. Agric. Food Chemist., 42: 1896-1900.

[12] FAO/WFP/IFAD, 2012. The state of food insecurity in the world. Economic growth is necessary but not sufficient to accelerate reduction of hunger and malnutrition. Rome, FAO. pp: 8.

[13] Fatoumata T., A. Issoufou, L. Guo-Wei and S. Yong-Hui, 2011. Effect of boiling on the physicochemical properties of Roselle seeds (Hibiscus sabdariffa L.) cultivated in Mali. Afr. J. Biotechnol., 10(79): 18160-18166.

[14] Friedewald W. T., R. I. Levy and D. S. Frederickson, 1972. Estimation of concentration of the Low Density Lipoprotein cholesterol in plasma, without use of preparative ultracentrifuge. Clin. Chem., 18: 499-502.

[15] Hainida E., I. Amin, H. Normah, N. Mohd-Esa, Ainul ZAB, 2008. Effects of defatted dried roselle (Hibiscus sabdariffa L.) seeds powder on lipid profiles of Hypercholesterolemia rats. J. Sci. Food Agric., 88: 1043-1050.

[16] Halimatul S. M. N., I Amin, N. Mohd-Esa, A. G. Nawalyah and M. Muskinah, 2007. Protein quality of Roselle (Hibiscus sabdariffa L.) seeds. ASEAN Food J., 14 (2): 131-140.

[17] I.C.N., 1992. International Conference of Nutrition, Biochemicals Catalog $n^{\circ} 103312$ and $n^{\circ} 960219$. Rome, Cleavaland.
[18] Jansman A. J. M., 1993. Tannins in feedstuff for simple stomached animals. Nutr. Res. Rev., 6: 209-236.

[19] Kessel C., 2005. Leaf analysis -what's the story. Nutrition (Horticulture)- Program Lead/OMAFRA. PP: 2-4.

[20] Marlett J. A., 2001. Dietary fibre and cardiovascular disease. In: Cho SS, Dreher ML (Eds) Handbook of dietary, Marcel Dekker Publisher, New York, USA, PP: 17-30.

[21] Mbah B. O., P. E. Eme and O. F. Ogbusu, 2012. Effect of cooking methods (boiling and roasting) on nutrients and anti-nutrients content of Moringa oleifera seeds. Pakistan J. Nutr., 11 (3): 211-215.

[22] Modi A. T., 2007. Growth temperature and plant age influence on nutritional on nutritional quality of amaranthus leaves and seed germination capacity. Crop Science, School of Agricultural Sciences and Agro business, University of KwaZulu-Natal, private bag X01, Scottsville 3201, South Africa.

[23] Mohamadou B. A., C. M. F. Mbofung and D. Thouvenot, 2007. Functional potential of a product from traditional biotechnology: antioxidant and probiotic potential of Mbuja, produced by fermentation of Hibiscus sabdariffa seeds Cameroon. J. Food Technol., 5 (2): 164-168.

[24] Parkouda C., B. Diawara and L. I. I. Ouoda, 2008. Technology and physic-chemical characteristics of Bikalga, alkaline fermented seeds of Hibiscus sabdariffa. Afr. J. Biotechnol., 7(7): 916-922.

[25] Pearson N. D., 1981. Pearson chemical analysis of food. H. Egon, R. S. Kirt and R. Sawyer, $8^{\text {th }}$. Edn. Churchill Livingstone London, New York.

[26] Price M. L., L. G. Butler, J. C. Rogler and W. R. Featherston, 1979. Overcoming the nutritionally harmful effects of tannin in sorghum grains by treatment with inexpensive chemicals. $J$ Agric. Food Chem., 27: 441-445.

[27] Rao P. U., 1996. Nutrient composition and biochemical evaluation of mesta (Hibiscus sabdariffa) seeds. Plant Foods for Human Nutrition, 49: 27-34.

[28] Samy M. S., 1980. Chemical and nutritional studies on roselle seeds (Hibiscus sabdariffa L.). Zeith Ernahrungswisse, 19: 47-49.

[29] Scharrer K. and K. Kürschner, 1931. Ein neues, rasch durchfuhrbares Verfahren zur Bestimmung der Rohfaser in Futtermitteln. Biedermans. Zbl. B. Tierernahrung. 3: 302.

[30] William J. A., I. L. Nasare, D. T-D., K. O-B. and K. B. Kentil, 2013. Nutrient composition of Moringa oleifera leaves from two agro ecological zones in Ghana. African Journal of Plant Science, 8(1): 65-71.

[31] Yacoub A. A. and A. A. Abdalla, 2007. Effect of domestic processing methods on chemical, in vitro digestibility of protein and starch and functional properties of Bambara groundnut (Voandzeia subterranean) seed. J. Agric. Biol. Sci., 3: 24-34. 